\title{
DPPH RADICAL SCAVENGING CAPACITY AND THE REDUCING POWER OF FREE AND BOUND PHENOLICS FROM WHEAT AND PORCINO (Boletus edulis) FLOURS
}

Jelena S. Stojanović1, Nada Č. Nikolić ${ }^{1}$, Miodrag L. Lazić1, Ivana T. Karabegović1, Jasna S. Mastilović ${ }^{2}$, Gordana S. Stojanović ${ }^{3}$

(ORIGINAL SCIENTIFIC PAPER)

1 University of Niš, Faculty of Technology, Leskovac, Serbia UDC 664.641.12+582.284.52:547.565

2University of Novi Sad, Institute of Food Technology, Novi Sad, Serbia

${ }^{3}$ University of Niš, Faculty of Science and Mathematics, Department of Chemistry, Niš, Serbia

In this paper the content, DPPH radical scavenging capacity and the chelating activity on $\mathrm{Fe}^{2+}$ of free and bound phenolics extract from wheat and porcino flours were determined. The content of phenolic compounds in the extracts of free and bound phenolics from the wheat flour was 4.49 and $196.79 \mu \mathrm{g} / \mathrm{g}$, and in the porcino flour these contents were 860.02 and $30.38 \mu \mathrm{g} / \mathrm{g}$, respectively. The content of total phenolics in the porcino flour was considerably higher than that in the wheat flour. For DPPH test, the $\mathrm{IC}_{50}$ the value of free and bound phenolics from the wheat flour was 2.48 and $0.23 \mathrm{mg} / \mathrm{ml}$, respectively, and these values for phenolics from the porcino flour were 0.22 and $0.06 \mathrm{mg} / \mathrm{ml}$, respectively. For reducing power, the $\mathrm{IC}_{50}$ value of free and bound phenolics from the wheat flour was 5.12 and $0.21 \mathrm{mg} / \mathrm{ml}$, and from the porcino flour it was 0.87 and $0.28 \mathrm{mg} / \mathrm{ml}$, respectively. Free and bound phenolics from the porcino flour have a better DPPH scavenging capacity, and free phenolics from the porcino flour have a better reducing power than phenolics from the wheat flour. The results show that the addition of porcino to wheat flour could improve the antioxidant potential of the wheat flour and of final food products which could be obtained from the wheat-porcino flour mixture.
Keywords: phenolics, scavenging capacity, reducing power, wheat, porcino, flour

\section{Introduction}

Phenolics are widely distributed in plants, and in recent years they are paid great attention due to their antioxidant activity such as free radical scavenging ability and chelating metal ions with important benefits to human health. Common wheat is an important component of the human diet and is used in the production of many food products. The wheat flour, especially from the whole grain, and its products contain a high level of antioxidants such as phenolics [1,2]. The consumption of the whole grain and bran may help in the prevention of cardiovascular diseases, diabetes and some cancer forms [3]. The majority of phenolics in a wheat grain are insoluble and bound by ester and ether linkages with polysaccharide, such as arabin-oxylan and lignin in the cell wall $[4,5]$ while a smaller portion is soluble i.e. free [6]. Phenolic acids represent the most common compounds of phenolics in wheat and are present mainly in bound forms, linked through the ester bond to the cell wall structural components such as cellulose, lignin and proteins [7]. The bound phenolics are considered to have a greater antioxidant capacity because they escape from gastrointestinal digestion along with the cell wall materials and are absorbed into the blood plasma during digestion by intestinal micro flora [1].
Bound phenolics are commonly extracted by alkaline $[6,8]$, but also could be liberated by acid hydrolysis or their combination [9].

Mushrooms are edible fungi and delicious nutritional food in many countries. The food value of mushrooms is between meat and vegetable [10]. During recent years the usage and consumption of mushrooms have increased, especially in the vegetarian community [11]. Crisan and Sands [12] reported that mushrooms in general contain $90 \%$ of water and $10 \%$ of dry matter and the content of protein in the dry matter varies in a wide range, from 10 to $40 \%$ [13]. Besides protein, mushrooms contain $3-21 \%$ of carbohydrates, $3-35 \%$ of dietary fibre [14], essential amino acids, B-vitamins and vitamin C [15]. Besides nutritional, mushrooms have medicinal importance. They have been used as medicine in China since 100 A.D., but the health benefits of basic active principles of mushrooms were promoted in 1960s and they have been used in health care for treating simple skin diseases $[16,17]$. The anti-tumour properties of aqueous extracts of edible mushrooms were reported by Ikekawa [18]. Bahl (1983) [19] reported that mushrooms cure epilepsy, wounds, skin diseases, heart ailments, rheumatoid arthritis, cholera, intermittent fevers,

\footnotetext{
*Author address: Nada Nikolić, Faculty of Technology, University of Niš, Bulevar oslobodjenja 124,16 000 Leskovac, Serbia

E-mail: nadanikolic64@yahoo.com

The manuscript received: Jun, 25, 2014.

Paper accepted: August, 20, 2014.
} 
diaphoretic, diarrhoea, dysentery, cold, anaesthesia, liver and gall bladder diseases, and are used as vermicides. Nowadays, the data show many other benefits of mushrooms in medicine, without side effects [20]. The extract of some edible mushrooms also showed the ability to protect polyunsaturated fatty acids from lipid peroxidation [21] and had the antioxidant activity [22]. It was determined that Boetus edulis had the total phenolics content of $41.82 \mathrm{mg}$ gllic acid equivalent per gram of the dry extract, and this content was higher than the total phenolics content in Boletus auranticus. By DPPH test it was found that Boletus edulis dry mushroom extract exhibited $50 \%$ of the inhibition value at the concentration of $0.016 \mathrm{mg} / \mathrm{ml}$ [22].

In literature available to us, there are no data about the content of free and bound phenolics from porcino mushroom and their antioxidant activity. Considering the nutritional properties and health benefits of the mushroom Boletus edulis and the increasing popularity of functional foods, the objective of the present work was to determine and compare the content and the radical scavenging capacity and reducing power of free and bound phenolics from the wheat flour type 500 and the flour of porcino originating from ecoregions. The aim of the paper was to evaluate the effect of the porcino flour addition to the wheat flour on the antioxidant potential of the flour mixture and final food products which could be obtained.

\section{Experimental}

\section{Wheat and porcino flours}

The wheat flour (WF), type 500 by "Fidelinka", Subotica, Serbia, was bought from the local market. The wild, fresh mushroom (Boletus edulis) originating from the ecoregion of Piskupovo, Leskovac, Serbia was used to obtain the porcino flour (PF). The fresh porcino was dried at $35^{\circ} \mathrm{C}$ until the moisture content of approximately $9 \%$ was reached, milled (IKA Model M120) and sieved through a $0.30 \mathrm{~mm}$ riddle.

\section{Extraction of free phenolics}

For the extraction of free phenolic compounds from the wheat flour and porcino flour, $5 \mathrm{~g}$ of the flour was measured and $50 \mathrm{ml}$ of methanol was added. The mixture was stirred with the MR1 magnetic stirrer (IKA-Werke, Staufen, Germany) for 30 minutes at $200 \mathrm{~min}^{-1}$ and vacuum filtered through No. 54 Wathman filter paper (GE Healthcare, Brondby, Denmark). The solids were re-extracted with $50 \mathrm{ml}$ of methanol and the filtrates combined and made to a final volume of $100 \mathrm{ml}$. For radical scavenging capacity (SC) and reducing power measurements, $80 \mathrm{ml}$ of each extract were evaporated in vacuum at $45^{\circ} \mathrm{C}$ until dry, and dissolved in $30 \mathrm{ml}$ of methanol.

\section{Extraction of bound phenolics}

For the extraction of the bound phenolic compounds from the wheat flour and porcino flour, the bound phenolics were first liberated by alkaline hydrolysis, as described by Verma et al. [9]. Briefly, $5 \mathrm{~g}$ of the flour residue in which free phenolics were previously removed, $150 \mathrm{ml}$ of distilled water and $50 \mathrm{ml} 6 \mathrm{M} \mathrm{NaOH}$ were mixed and left to stand at room temperature $24 \mathrm{~h}$. Then the $\mathrm{pH}$ was adjusted to two with $6 \mathrm{M} \mathrm{HCl}$. Dyethylether and ethylacetate mixture in ratio $1: 1 \mathrm{v} / \mathrm{v}(150 \mathrm{ml})$ was added to the mixture and left to stand for $3 \mathrm{~h}$. The mixture inverted after every 30 minutes and after $3 \mathrm{~h}$, the upper layer was removed, evaporated to dry and the residue was dissolved in $10 \mathrm{ml}$ of methanol.

\section{Phenolic compounds content}

The phenolic compounds contents in the extracts of free and bound phenolics from WF and PF were determined by using Folin-Ciocalteu reagent [23]. The methanolic extracts of free and bound phenolic $(0.2 \mathrm{ml})$ were mixed with the Folin-Ciocalteu reagent $(1 \mathrm{ml})$ into test tubes. The aqueous solution of $\mathrm{Na}_{2} \mathrm{CO}_{3}(0.8 \mathrm{ml}, 7.5 \% \mathrm{~m} / \mathrm{v})$ was added after $8 \mathrm{~min}$. After $30 \mathrm{~min}$ of incubation at room temperature, the absorbance was measured at $765 \mathrm{~nm}$ by UV 21000 Spectrophotometer (Cole Parmer Instruments Company, Vernon Hills, Illinois, USA). For the phenolic content determination, a curve based on five concentrations of gallic acid (Sigma Chemical, St. Louis, Missouri, USA) as standard, covering the range from 10 to $300 \mu \mathrm{M}$, was made. The phenolics content was ca-lculated based on the equation $\mathrm{C}=237.05 \times \mathrm{Ab}-12.69$ and expressed as $\mu \mathrm{g}$ of gallic acid equivalents per $\mathrm{g}$ of flour.

\section{DPPH radical scavenging capacity}

The radical scavenging capacity (SC) of the extracts of free and bound phenolics from WF and PF, diluted by methanol to the concentrations in range from 0.3 to $8 \mathrm{mg} /$ $\mathrm{ml}$ was determined by the DPPH test. The methanol solution of the DPPH radicals concentration of $0.1 \mathrm{mM}(1 \mathrm{ml})$ was added to $2.5 \mathrm{ml}$ methanolic extract and allowed to react at room temperature during $30 \mathrm{~min}$. Then, the absorbance at $518 \mathrm{~nm}$ was measured on UV 21000 Spectrophotometer (Cole Parmer Instruments Company, Vernon Hills, Illinois, USA) and converted into the percentage of radical SC by using the equation previously defined by Mensor and Menezes [24]:

$\mathrm{SC}=100-\frac{\left(A_{\text {sample }}-A_{\text {blank }}\right)}{A_{\text {control }}} \times 100$

where $A_{\text {sample }}$ is the absorbance at $518 \mathrm{~nm}$ of the ethanol solution of the extract treated by the $\mathrm{DPPH}$ radical solution; $A_{\text {blank }}$ is absorbance at $518 \mathrm{~nm}$ of the ethanol solution of the extract ( $1 \mathrm{ml}$ of ethanol added to $2.5 \mathrm{ml}$ of extract), and $A_{\text {control }}$ is absorbance at $518 \mathrm{~nm}$ of ethanol solution of DPPH radical $(1 \mathrm{ml}$ of a $0.3 \mathrm{mM}$ added to $2.5 \mathrm{ml}$ of ethanol). The final results are presented as $I_{50}$ value, i.e. the concentration of the studied extracts that causes a decrease in the initial DPPH concentration by $50 \%$. The IC50 value was calculated by using Microsoft Excel ed50plus v1.0 software by Mario H. Vargas, Instituto Nacionale de Enfermedades Respiratories. Butylated hydroxyanisole was used as a standard. 


\section{Reducing power}

The chelating activity on $\mathrm{Fe}^{2+}$, i.e. the reducing power of the extracts of free and bound phenolics from WF and PF, were determined by the method described by Oyaizu [25]. Methanolic extracts $(2.5 \mathrm{ml})$ various concentrations ( 0.3 to $8 \mathrm{mg} / \mathrm{ml}$ ) were mixed with $2.5 \mathrm{ml}$ of phosphate buffer (0.2M, pH 6.6) and $2.5 \mathrm{ml}$ of $1 \%$ potassium ferycynide. The mixture was incubated during $20 \mathrm{~min}$ at $50{ }^{\circ} \mathrm{C}$. After the incubation, $2.5 \mathrm{ml}$ of $10 \%$ trichloracetic acid solution was added and the mixture centrifuged for $10 \mathrm{~min}$ (3000 rpm). The obtained supernatant $(2.5 \mathrm{ml})$ was mixed with bi-distilled water $(2.5 \mathrm{ml})$ and the $0.1 \% \mathrm{FeCl}_{3}$ solution $(0.5 \mathrm{ml})$. The absorbance of the coloured solution was measured at $700 \mathrm{~nm}$. A higher absorbance indicated a higher reducing power. Butylated hydroxyanisole was used as a standard.

\section{Statistical analysis}

Statistica version 5.0 Software (StatSoft, Tulsa, Oklahoma, USA) was used to perform the statistical analysis. The mean and standard deviations were obtained by using Descriptive Statistics, marking the Median \& Quartiles and Confirm Limits for Means.

\section{Results and discussion}

The content of free and bound phenolic compounds and $\mathrm{IC}_{50}$ value for of $\mathrm{DPPH}$ test and reducing power in the extracts of free $(A)$ and bound $(B)$ phenolics from the wheat (WF) and porcino flour (PF) are shown in Table 1. The values are the means and standard deviation $(\mathrm{N}=3)$.

Table 1. The content of total phenolic compounds and IC50 value for the DPPH test and the reducing power test of free and bound phenolics from the wheat (WF) and porcino flour (PF)

\begin{tabular}{|c|c|c|c|c|}
\hline & \multicolumn{2}{|c|}{ WF } & \multicolumn{2}{|c|}{ PF } \\
\hline & Free & Bound & Free & Bound \\
\hline Content of phenolic compounds ${ }^{*}$ & $4.49 \pm 0.63$ & $196.79 \pm 2.34$ & $860.02 \pm 6.72$ & $30.38 \pm 2.89$ \\
\hline Total content (free and bound) & \multicolumn{2}{|c|}{201.28} & \multicolumn{2}{|c|}{890.40} \\
\hline IC $_{50}^{* *}(\mathrm{DPPH}$ test $)$ & 2.48 & 0.23 & 0.22 & 0.06 \\
\hline $\mathrm{IC}_{50}{ }^{* *}$ (Reducing power) & 5.12 & 0.21 & 0.87 & 0.28 \\
\hline
\end{tabular}

The content of phenolic compounds in the extracts of free and bound phenolics from the wheat flour was 4.49 and $196.79 \mu \mathrm{g} / \mathrm{g}$, respectively, and in the porcino flour this content was 860.02 and $30.38 \mu \mathrm{g} / \mathrm{g}$, respectively $[26,27]$. The results show that the content of free phenolics from the wheat flour was considerably, even 43.8 times lower than of bound phenolics. In the porcino flour the situation is opposite and free phenolics were 28.3 times higher than bound phenolics. This indicates that the phenolics in the investigated wheat flour sample

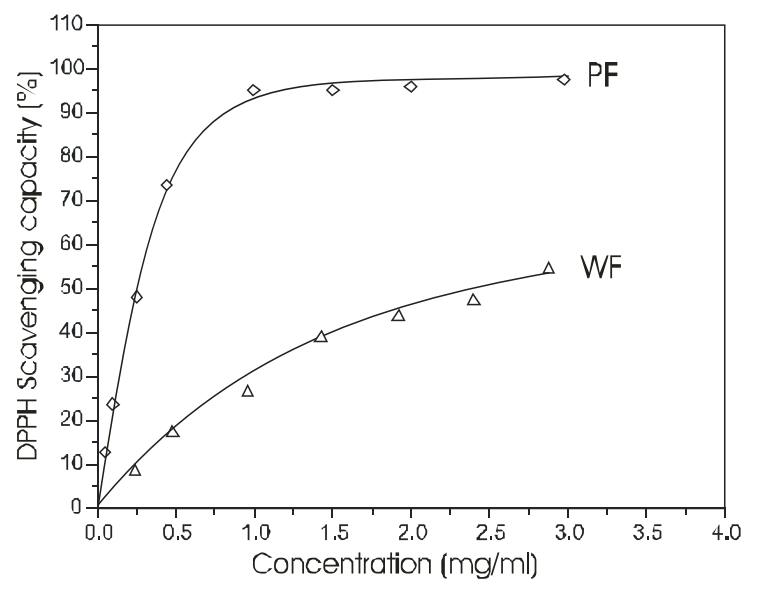

(A) are mainly present in a bound form, as earlier investigation by Paker, et al. [7] also showed, while in the porcino flour phenolics are mainly present in a free form. Comparing the contents of phenolics in wheat and porcino flours, the content of free phenolics and the content of total phenolics (obtained by content summation of free and bound phenolics), was higher in the porcino flour than in the wheat flour. Based on these results, this is the first sign that the porcino flour could improve the antioxidant potential, as well as health benefits of the wheat flour.

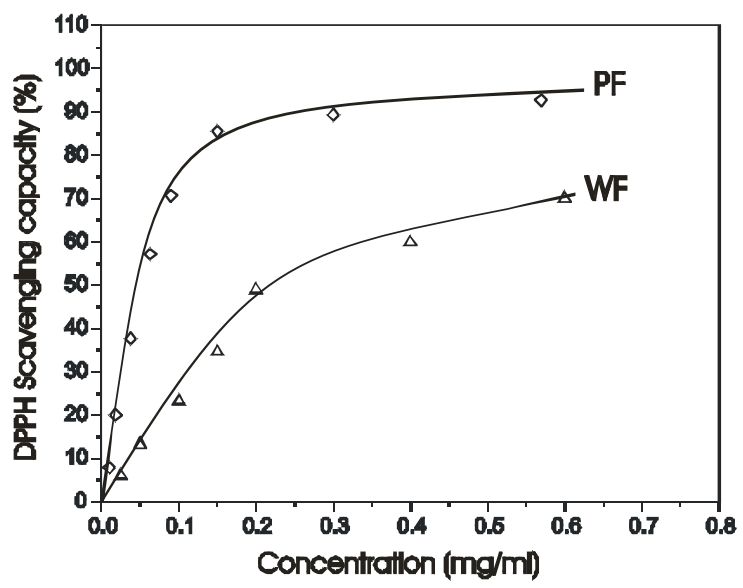

(B)

Figure 1. The dependence of DPPH scavenging capacity of free $(A)$ and bound $(B)$ phenolics from the wheat (WF) and porcino flour (PF) on the concentration of the extract 
The results of the dependence of DPPH scavenging capacity on the concentration of the extract of free and bound phenolics from wheat and porcino flours are shown in Figure 1, and the results of the dependence of the reducing power on the concentration of these extracts are shown in Figure 2. The investigations of the antioxidant activity showed that the DPPH scavenging capacity and reducing power depended on the extract concentration and it increased with the increase of the extract concentration.

The $\mathrm{IC}_{50}$ values of free and bound phenolics from the wheat flour were 2.48 and $0.23 \mathrm{mg} / \mathrm{ml}$, respectively, and these values for the extracts from the porcino flour were 0.22 and $0.06 \mathrm{mg} / \mathrm{ml}$, respectively. For the reducing power, the $\mathrm{IC}_{50}$ value of the extract of free and bound phenolics from the wheat flour was 5.12 and $0.21 \mathrm{mg} /$ $\mathrm{ml}$, and from the porcino flour it was 0.87 and $0.28 \mathrm{mg} /$ $\mathrm{ml}$, respectively. As a lower $\mathrm{IC}_{50}$ value indicates a higher scavenging capacity, i.e. reducing power, the obtained results show that the extract of bond phenolics from the wheat flour has almost ten times higher DPPH scaveng-

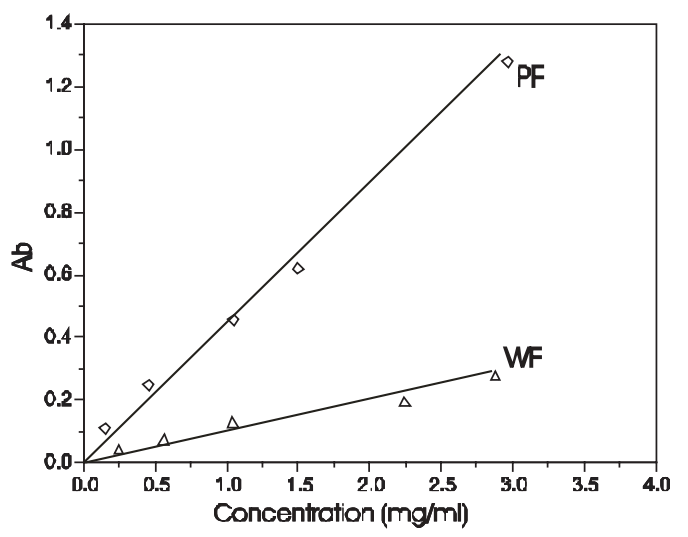

(A) ing capacity and almost twenty-five times higher chelating activity on $\mathrm{Fe}^{2+}$ than the extract of free phenolics, and bond phenolics from the porcino flour have nearly four times (3.8 times) higher scavenging capacity of DPPH radical and about three times higher chelating activity on $\mathrm{Fe}^{2+}$ than free phenolics.

Comparing the results for wheat and porcino flours, the extract of free phenolics from the porcino flour have better DPPH scavenging capacity and chelating activity on $\mathrm{Fe}^{2+}$ than the extract of free phenolics from the wheat flour. Also, the extract of bound phenolics from the porcino flour had better DPPH radical scavenging capacity, but lower chelating activity on $\mathrm{Fe}^{2+}$ than the extract of bound phenolics from the wheat flour, as shown in Figure 2.

Butylated hydroxyanisole in the DPPH scavenging capacity test showed that the concentration necessary for reaching $\mathrm{IC}_{50}$ was $2.92 \mu \mathrm{g} / \mathrm{ml}$, and in the reducing power test it was $3.73 \mu \mathrm{g} / \mathrm{ml}$. The results showed that all the investigated extracts had much lower DPPH scavenging capacity, as well as chelating activity on $\mathrm{Fe}^{2}$ than this compound.

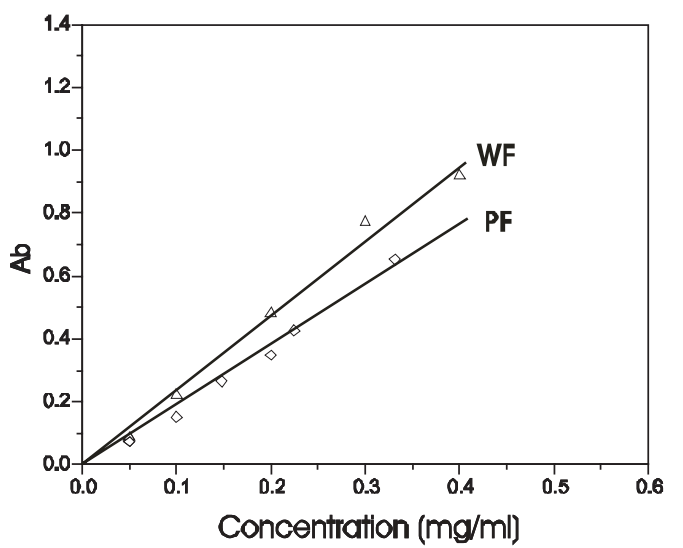

(B)

Figure 2. The dependence of absorbance in the reducing power test for free $(A)$ and bound $(B)$ phenolics from wheat (WF) and porcino flour (PF) on the concentration of the extract

\section{Conclusion}

The phenolics in the wheat flour were mainly present in a bound form while in the porcino flour they were present in a free form, as the content of free phenolics in the wheat flour was considerably lower than the content of bound phenolics (even 43.8 times) and in the porcino flour the content of free phenolics was 28.3 times higher than the content of bound phenolics. The content of total phenolics obtained as a sum of free and bound phenolics in the porcino flour was considerably higher than in the wheat flour. The extract of free phenolics from the porcino flour had better DPPH scavenging capacity and reducing power than the extract of free phenolics from the wheat flour. Also, the extract of bound phenolics from the porcino flour had better DPPH radical scavenging capacity but lower reducing power than the extract of bound phenolics from the wheat flour. Generally, it is real to expect that the addition of porcino to the wheat flour will improve the antioxidant potential of the wheat flour and final food products obtained from wheat and porcino flours mixture.

\section{Acknowledgement}

This work is supported by the Ministry of Education, Science and Technological Development of the Republic of Serbia, under the project 172047. 


\section{References}

[1] K. Adam, H. Liu, Antioxidant activity of grains, Journal of Agricultural and Food Chemistry, 50 (2012) 6182-6187.

[2] L. Wang, Y.Yao, Z. He, D. Wang, A. Liu, Y. Zhang, Determination of phenolic acid concentrations in wheat flours produced at different extraction rates, Journal of Cereal Science, 57 (2013) 67-72.

[3] J. Slavin, D. Jacob, L. Marquart, Whole grain consumption and chronic diseases: Protective mechanisms, Nutrition Cancer, 27 (1997) 14-21.

[4] M. Liyana-Patrhirana, F. Shahidi, The antioxidant potential of milling fraction from bread wheat and durum, Journal of Agricultural and Food Chemistry, 54 (2006) 1256-1264.

[5] A. Renger, H. Steinhart, Ferulic acid dehydrodime as structural elements in cereal dietary fibre, European Food Research and Technology, 211 (2004) 422-428.

[6] D. Stalikas, Extraction, detection and separation methods for phenolic acids and flavonoids, Journal of Separation Science, 30 (2007) 3268-3295.

[7] I. Parker, A. Ng, W. Waldron, The phenolics acid and polysaccharide composition of cell walls bran layer of mature wheat (Triticum aestivum L. Cv. Avalon) grains, Journal of Agricultural and Food Chemistry, 85 (2005) 2539-2547.

[8] K. Krygier, F. Sosulki, L. Hogge, Free, esterified and insoluble bound phenolic acids. I. Extraction and purification procedure. Journal of Agricultural and Food Chemistry, 30 (1982) 330-334.

[9] B.Verman, P. Hucl, R.Chibbar, Phenolic acid and antioxidant capacity of acid and alkali hydrolysed wheat bran fraction, Food Chemistry, 116 (2009) 947-954.

[10] Z. Bano, Nutritive value of Indian mushroom and medicinal practices, Economic Botany, 31 (1976) 367-371.

[11] G. Shakuntala, B. Samudra, V. Deepak, C. Sudeshna, Fungal biotechnology in food and feed processing. Food Research International, 42 (2009) 577-587.

[12] E. Crisan, A. Sands, A nutritive value of edible mushrooms, in: S. Chang, A. Hayes (Ed.), The biology and cultivation of edible mushrooms, Academic Press, New York and London, 1978, p. 172.

[13] I. Friedman, Protein nutritional quality of foods and feeds, Marcel Dekker Inc., New York, 1975, p. 98.

[14] V. Mallavadhani, S. Sudharkar, S. Satyanarayana, A. Mahapatra, W. Li, B. Van Breemen, Chemical and analytical screening of some edible mushrooms, Food Chemistry, 95 (2006) 58-64.

[15] P. Kalač, Chemical composition and nutrition value of European spices of wild growing mushroom, in: $\mathrm{S}$. Andresand, N. Baumann (Ed.), Mushrooms: Types properties and nutrition, Nova Science Publishers, New York, 2012, p. 129.

[16] W. Breene, Nutritional and medicinal value of speciality mushrooms. Journal of Food Protection, 53 (1990) 883894.

[17] N. Gunde-Cimmerman, Medicinal value of the genus Pleurotus (Fr.) P. Karst. (Agaricales S.I., Basidiomycetes). International Journal of Medicinal Mushrooms, 1 (1999) 69-80.

[18] T. Ikekawa, N. Uehara, Y. Maeda, M. Nakanishi, F. Fukuoka, Antitumour activity of aqueous extracts of edible mushrooms, Cancer Research, 29 (1969) 734-735.

[19] N. Bahl, Medicinal value of edible fungi, in: Proceedings of the International Conferences on Science and Cultivation technology of Edible Fungi, Indian Mushrooms Science II, 1983, 203-209.

[20] W. Bilal, H. Bodha, H. Wani, Nutritional and medicinal importance of mushrooms, Journal of Medicinal Plants Research, 4 (2010) 2598-2604.

[21] L. Barros, J. Barreira, C. Grangeia, C. Batista, V. Cadavez, I. Ferreira, Beef burger patties incorporated with Boletus edulis extracts: Lipid peroxidation inhibition effects, European Journal of Lipid Science and Technology, 113 (2011) 737-743.

[22] S. Vidović, I. Mujić, Z. Zeković, Ž. Lepojević, V. Tumbas, A. Mujić, Antioxidant properties of selected Boletus mushrooms, Food Biophysics 5 (2010) 49-58.

[23] L. Singleton, Jr. Rossi, Colorimetry of total phenolics with phosphomolybdate-phosphotungestic acid reagents, American Journal of Viticulture and Anology, 16 (1965) 144-158.

[24] L. Mensor, F. Menezes, G. Leitão, A. Reis, T. dos Santos, C. Coube, S. Leitão, Sreening of Brazilian plant extracts for antioxidant capacity by the use of DPPH free radical method, Phototherapy Research, 15 (2001) 127-130.

[25] M. Oyaizu, Studies on product of browning reaction prepared from glucose amine, Japanese Journal of Nutrition, 44 (1986) 307-315.

[26] J. Stojanović, N. Nikolić, M. Lazić, I. Karabegović, G. Stojanović, Scavenging capacity of DPPH radical and reducing power of free and bound phenolics from porcino (Boletus edulis) flour, International Conference on Natural Products Utilization: From plants to pharmacy Shelf, Bansko, Bulgaria, Book of abstracts, 2013, p. 164.

[27] N. Nikolić, J. Stojanović, M. Mičić, M. Lazić, I. Karabegović, G. Stojanović, Scavenging capacity of DPPH radical and reducing power of free and bound phenolics of wheat flour, Okolišni potencijali, održivi razvoj i proizvodnja hrane, Tuzla, Bosna i Hercegovina, Zbornik sažetaka, p. 14. 
Izvod

\section{KAPACITET NEUTRALISANJA DPPH RADIKALA I REDUKCIONA SNAGA SLOBODNIH I VEZANIH POLIFENOLA BRAŠNA PŠENICE I VRGANJA (Boletus edulis)}

Jelena S. Stojanović1 ${ }^{\text {, Nada Č. Nikolić }}{ }^{1}$, Miodrag L. Lazić ${ }^{1}$, Ivana T. Karabegović1, Jasna S. Mastilović ${ }^{2}$, Gordana S. Stojanović ${ }^{3}$

1 Univerzitet u Nišu, Tehnološki fakultet, Leskovac, Srbija UDC 664.641.12+582.284.52:547.565

2Univerzitet u Novom Sadu, Institut za prehrambene tehnologije, Novi Sad, Srbija

3 Univerzitet u Nišu, Prirodno-matematički fakultet, Odsek za hemiju, Niš, Srbija

U radu je ispitan sadržaj, kapacitet neutralisanja DPPH radikala i sposobnost heliranja jona $\mathrm{Fe}^{2+}$, slobodnih i vezanih polifenola brašna pšenice i vrganja. Sadržaj slobodnih i vezanih polifenola pšeničnog brašna bio je 4,49 odnosno 196,79 $\mu \mathrm{g} / \mathrm{g}$, a brašna vrganja, 860,02 odnosno $30,38 \mu \mathrm{g} / \mathrm{g}$. Rezultati ukazuju da su polifenoli u pšeničnom brašnu uglavnom bili prisutni u vezanom, a u brašnu vrganja u slobodnom obliku. Sadržaj ukupnih polifenola u brašnu vrganja bio je značajno veći u odnosu na sadržaj u pšeničnom brašnu. Vrednost $\mathrm{IC}_{50} \mathrm{DPPH}$ testa slobodnih i vezanih polihenola pšeničnog brašna bila je 2,48 odnosno 0,23 $\mathrm{mg} / \mathrm{ml}$, dok je za polifenole brašna vrganja iznosila 0,22 odnosno 0,06 mg/ml. $\mathrm{U}$ slučaju testa redukcione snage, vrednost $\mathrm{IC}_{50}$ slobodnih i vezanih polifenola pšeničnog brašna bila je 5.12 odnosno $0,21 \mathrm{mg} / \mathrm{ml}$, a za polifenole brašna vrganja, 0,87 odnosno $0,28 \mathrm{mg} / \mathrm{ml}$. Ekstrakt slobodnih i vezanih polifenola vrganja imao je bolji kapacitet neutralisanja DPPH radikala i jaču redukcionu snagu, a ekstrakt vezanih polifenola bolji kapacitet neutralisanja DPPH radikala u odnosu na ekstrakt pšeničnog brašna. Rezultati ukazuju na mogućnost primene brašna vrganja za zamenu dela pšeničnog brašna u cilju poboljšanja antioksidativnog potencijala mešavine brašna i finalnih prehrambenih proizvoda.

Ključne reči: polifenoli, kapacitet neutralisanja radikala, redukciona snaga, pšenica, vrganj, brašno 